Vol. 6(1997): 241-245.

\author{
Research Note
}

\title{
DNA fingerprinting demonstrates extremely low levels of genetic variation among blackberry cultivars grown in Finland
}

\author{
Kristiina Antonius \\ Department of Plant Biology, University of Helsinki, Finland. Current address: Department of Biosciences, \\ Division of Genetics, PO Box 56, FIN-00014 University of Helsinki, Finland, \\ email: kristiina.antonius@helsinki.fi \\ Gun Werlemark, Hilde Nybom \\ Balsgård-Department of Horticultural Plant Breeding, Swedish University of Agricultural Sciences, \\ Fjälkestadsvägen 123-1, S-291 94 Kristianstad, Sweden
}

\begin{abstract}
Most blackberry plants cultivated in Finland closely resemble the American species Rubus allegheniensis. Thirty nine such blackberry accessions in the University of Helsinki clone collection were studied by hybridization-based DNA fingerprinting and compared with some known cultivars of $R$. allegheniensis derivation. 'Imperial' appears to be identical to the old cultivar 'Majestät', but 'Earliest of All' differs considerably. In addition, 37 of the accessions analysed also have DNA fingerprints that appear to be completely identical to that of 'Majestät'! The remaining two accessions, although identical to each other, exhibit one band not found in 'Majestät' that is probably caused by a somatic mutation.
\end{abstract}

Key words: apomixis, clone, molecular marker, M13 probe, RFLP, Rosaceae, Rubus allegheniensis, Rosaceae

\section{Introduction}

Blackberry (Rubus spp.) cultivation in Finland is severely hindered by insufficient winter hardiness and late fruit ripening in the available plant material. The spring weather, with its extreme daily temperature fluctuations, is particularly damaging as it causes frost dehydration of otherwise healthy tissue when the ground is still frozen.

Nevertheless, blackberries have long been grown successfully in sheltered gardens (Immo- nen 1986, Selonen and Tigerstedt 1989). Dissemination and variation within the blackberry group were studied by Viksten (1984) with a view to broadening the selection of suitable plant material. Information on blackberry plants in cultivation was requested from the public through media announcements.

Of the more than 200 blackberry plants reported, 100 were chosen to establish a collection representing different species, cultivars and provenances. Only a few contributors provided information on cultivar identity; most accessions were identified through field observations and

(C) Agricultural and Food Science in Finland

Manuscript received April 1997 


\section{AGRICULTURAL AND FOOD SCIENCE IN FINLAND}

Antonius, $K$. et al. DNA fingerprinting of Finnish blackberry cultivars

by comparison with herbarium specimens at the University of Helsinki to species level only.

No fewer than 74 of the 100 accessions closely resembled $R$. allegheniensis, a widely distributed North American species. Partly due to its outstanding winter hardiness, this species has been important in plant breeding, and numerous successful cultivars have arisen from its tetraploid hybrids with other species (Jennings 1988). One such is probably 'Majestät', a popular cultivar reported to be of American origin (Reimer 1948) although its exact derivation is unknown. Morphologically it is similar to wild material of $R$. allegheniensis.

The present study was undertaken in an effort to provide the unidentified $R$. allegheniensis-type accessions with cultivar names by comparing their DNA fingerprints with those of known cultivars.

\section{Material and methods}

Leaf samples were taken from all of the $39 R$. allegheniensis- type accessions hitherto unidentified by cultivar, as well as from three cultivars on the same collection: 'Majestät', 'Imperial' and 'Earliest of All'. 'Imperial' was obtained from the Institute of Horticulture, the Agricultural Research Centre of Finland, at Piikkiö, and 'Earliest of All' from Rastlösa at Jorvas, Kirkkonummi, Finland. Three accessions of 'Majestät' were included in the analysis: one obtained from Turku Horticultural School, Finland; one from Professor E. Kaukovirta of the Department of Horticulture, University of Helsinki, Finland; and one from Poland through Paul Olsson's plant nursery in Finland. 'Imperial' and 'Majestät' are strikingly similar, but 'Earliest of All' deviates in having darker and more reddish foliage and thornfree canes. The latter also appears to be more susceptible to winter injury.

Healthy-looking and young, not yet fully expanded leaves were collected from field-grown plants on the day before DNA extraction, and kept overnight at $+4{ }^{\circ} \mathrm{C}$. DNA was isolated according to Nybom and Schaal (1990), with some minor modifications and an additional salt precipitation step (Graham et al. 1996). Separate aliquots of $8 \mu \mathrm{g}$ DNA were digested with the restriction enzyme HaeIII and electrophoresed on $0.7 \%$ agarose gels in TPE buffer according to Nybom and Schaal (1990). After Southern blotting to Magnagraph (MSI) nylon membrane, the samples were hybridized with a ${ }^{32} \mathrm{P}$ hexamer-labelled minisatellite DNA probe derived from the bacteriophage M13 (Nybom and Schaal 1990, Antonius and Nybom 1994). Autoradiograhps were developed for 2 weeks at $-80{ }^{\circ} \mathrm{C}$ using intensifying screens. Membranes were subsequently stripped and rehybridized with a synthetic (AC)/(TG) polydinucleotide probe as previously described (Antonius and Nybom 1994).

\section{Results and discussion}

DNA fingerprinting, based on the hybridization of restriction-enzyme digested DNA samples to hypervariable minisatellite DNA probes, has previously proved its ability to discriminate between closely related Rubus genotypes (Nybom et al. 1989, Nybom and Hall 1991). In this study, we obtained clear and informative DNA fingerprints after hybridization of the various Rubus accessions (Fig. 1). The cultivars 'Majestät' and 'Earliest of All' had different DNA band patterns, 'Majestät' having six bands not present in 'Earliest of All', and this cultivar having seven bands not present in 'Majestät'. At least another four bands appeared in the same position in all samples. This level of inter-cultivar differentiation is of the same magnitude as that previously reported among blackberry cultivars (Nybom et al. 1989, Nybom and Hall 1991).

Our sample of 'Imperial' turned out to be completely identical to that of 'Majestät'. However, samples of 'Imperial' derived from other sources should also be analysed to rule out the 


\section{AGRICULTURAL AND FOOD SCIENCE IN FINLAND}

Vol. 6 (1997): 241-245.

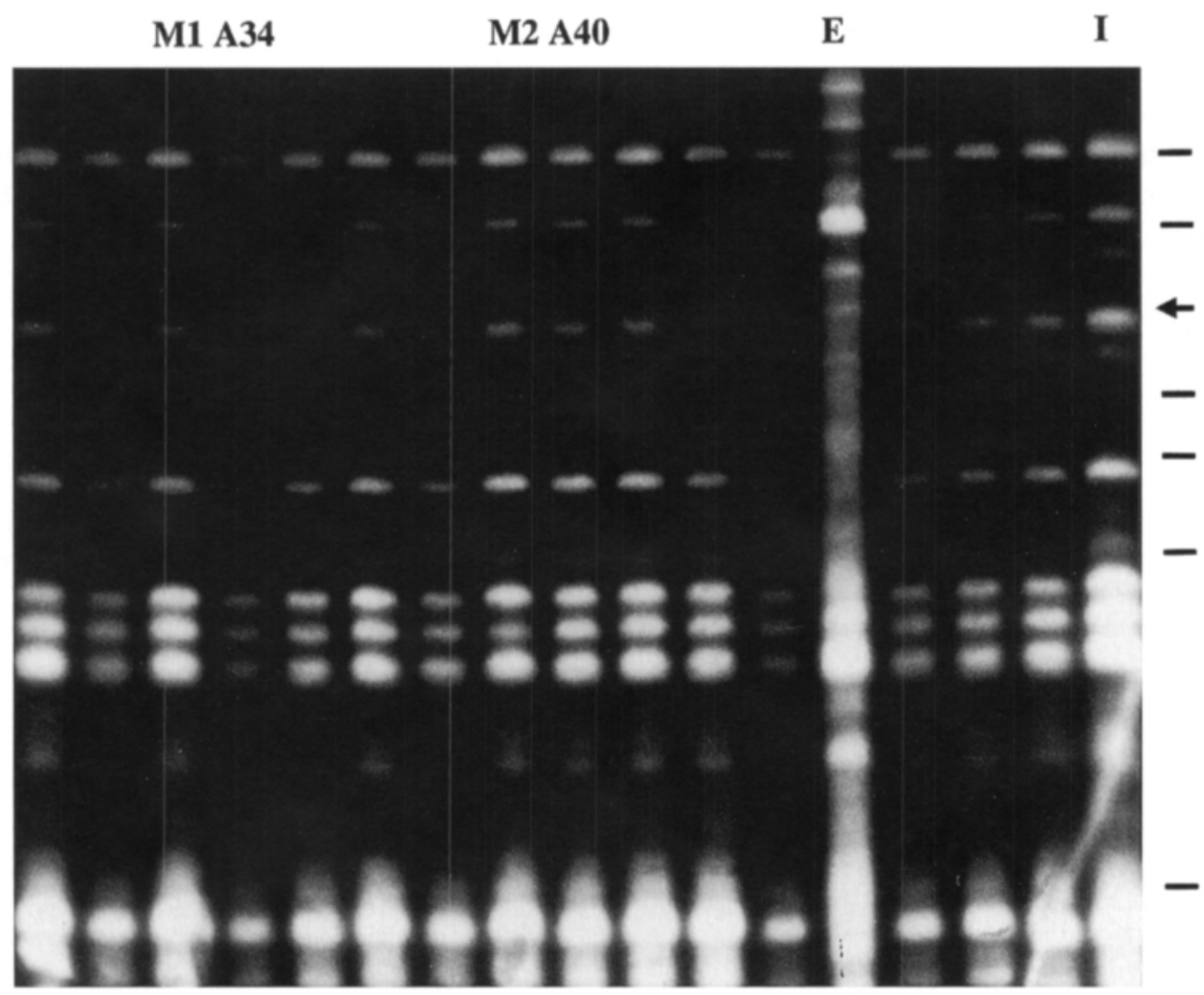

Fig. 1. Contact copy of an autoradiopraph with DNA fingerprints from hybridization of HaeIII-digested DNA samples to an M13 minisatellite DNA probe; M1='Majestät' from Turku, M2='Majestät' form Helsinki, E='Earliest of All', I='Imperial'; the remainder are previously unidentified accessions in the Helsinki Rubus collection. A34 and A40 are two accessions, each with one additional band (position shown by arrow), compared with the standard DNA fingerprint for 'Majestät'. Size markers in the right-hand margin $(7.2,6.4,4.8,4.3,3.7$ and $2.3 \mathrm{~kb})$ were obtained from a $\lambda$ DNA-BstEII digest.

possibility of misidentification of the plant material used in our study.

Surprisingly, 37 of the 39 previously unidentified accessions showed exactly the same band pattern as 'Majestät'. The two exceptions, A34 and $\mathrm{A} 40$, had one additional DNA band in the same position, but were otherwise completely identical to 'Majestät'. Whereas pathogenic infestation cannot be completely ruled out as the cause of this extra band, a somatic mutation involving some chromosomal rearrangement is more likely. Somatic mutations have previously been shown to cause very little (if any) variation in the DNA fingerprints, e.g. among sports of apple cultivars (Nybom 1990). By contrast, genetic recombination due to sexual seed set in blackberries generally gives rise to widely different band patterns (Nybom 1995).

Hybridization with the $(\mathrm{AC}) /(\mathrm{TG})$ probe yielded DNA fingerprints of same complexity as with the M13 probe but, as previously reported in Rubus (Antonius and Nybom 1996), these bands were less distinct and consequently more difficult to score. Only two patters were found: 'Earliest of All' showed three bands not present in the other samples, whereas these showed four bands not present in 'Earliest of All'. At least another ten bands appear to be in the same position for all samples analysed.

Chromosome level is closely associated with the reproductive system in blackberry taxa, diploid species being sexual and polyploid species 
Antonius, K. et al. DNA fingerprinting of Finnish blackberry cultivars

facultatively apomictic, i.e. able to produce seeds without prior fertilization (Nybom 1988). Although the wild species $R$. allegheniensis has been reported to be diploid (Jennings 1988), Finnish accessions of its putative derivative, 'Majestät', have previously proved to be tetraploid and apomictic as deduced from chromosome counts and from evaluation of offspring derived from cross-pollination experiments (Antonius and Nybom 1996). Consequently, seed collected from 'Majestät' would mainly produce plants identical to the seed parent. This could be one explanation for the identical DNA fingerprint patterns of 'Majestät' and 'Imperial'.
Immonen (1986) mentions another blackberry cultivar, 'Wilson's Frühe', which has been on sale in Finland and is apparently identical to 'Majestät'. Obvioulsy this single cultivar has been renamed several times. Most blackberries grown in Finland closely resemble $R$. allegheniensis (Hämet-Ahti et al. 1992), and the results of our study indicate that only one cultivar in this group, 'Majestät', has become really successful.

Acknowledgements. Financial support was received from the Finnish Ministry of Agriculture and Forestry, and from the Swedish Research Council for Agricultural Sciences.

\section{References}

Antonius, K. \& Nybom, H. 1994. DNA fingerprinting reveals significant amounts of genetic variation in a wild raspberry Rubus idaeus population. Molecular Ecology 3: 177-180.

- \& Nybom, H. 1996. Discrimination between sexual recombination and apomixis/automixis in a Rubus plant breeding programme. Hereditas 123: 205-213.

Graham, J., McNicol, R.J. \& McNicol, J. W. 1996. A comparison of methods for estimation of genetic diversity in strawberry cultivars. Theoretical and Applied Genetics 93: 402-406.

Hämet-Ahti, L, Palmen, A., Alanko, P. \& Tigerstedt, P.M.A. 1992. Suomen puu- ja pensaskasvio. Publications of the Finnish Dendrological Society 6: 1-373.

Immonen, A.S.T. 1986. Variation within the blackberry group under extreme climatic conditions in Finland. Acta Horticultuae 183: 25-32

Jennings, D.L. 1988. Raspberries and blackberries: their breeding, diseases and growth. Academic Press, London. $230 \mathrm{p}$.

Nybom, H. 1988. Apomixis versus sexuality in blackberries (Rubus subgen. Rubus, Rosaceae). Plant Systematics and Evolution 160: 207-218
- 1990. DNA fingerprints in sports of 'Red Delicious' apples. HortScience 25: 1641-1642.

- 1995. Evaluation of interspecific crossing experiments in facultatively apomictic blackberries (Rubus subgen. Rubus) using DNA fingerprinting. Hereditas 122: 57-65.

- \& Hall, H. 1991. Minisatellite DNA "fingerprints" can distinguish Rubus cultivars and estimate their degree of relatedness. Euphytica 53: 107-144.

- \& Schaal, B.A. 1990. DNA "fingerprints" reveal genotypic distributions in natural populations of blackberries and raspberries. American Journal of Botany 77: 883-888.

- , Schaal, B.A. \& Rogstad, S.H. 1989. DNA "fingerprints" can distinguish cultivars of blackberries and raspberries. Acta Horticulturae 262: 305-310.

Reimer, C. 1948. Bärodling. Nordisk Rotogravyr, Stockholm. $276 \mathrm{p}$.

Selonen, K. \& Tigerstedt, P.M.A. 1989. The use of interspecific crosses in breeding winterhardy blackberries in Finland. Acta Horticulturae 262: 133-139.

Viksten, A. 1984. Suomessa viljeltävistä karhunvatukoista. University of Helsinki, Library of Botany. MSc Thesis. $72 \mathrm{p}$. 


\title{
AGRICULTURAL AND FOOD SCIENCE IN FINLAND
}

Vol. 6 (1997): 241-245.

\section{SELOSTUS}

\section{Suomessa viljeltävissä karhunvatukkalajikkeissa hyvin vähän geneettistä vaihtelua}

\author{
Kristiina Antonius, Gun Werlemark, Hilde Nybom \\ Helsingin yliopisto ja Swedish University of Agricultural Sciences
}

Saatavilla olevien taimien heikko talvenkestävyys ja marjojen myöhäinen kypsyminen vaikeuttavat karhunvatukoiden (Rubus spp.) viljelyä Suomessa. Viksten etsi tutkimuksessaan Suomessa menestyviä karhunvatukoita tiedotusvälineissä julkistettujen kyselyjen avulla. Vastausten perusteella Helsingin yliopistolle kerättiin n. 100 karhunvatukkanäytteen kloonikokoelma. Näistä 74 kloonia muistuttaa läheisesti Pohjois-Amerikassa laajalle levinnyttä Rubus allegheniesis -lajia. Lajiketiedot puuttuivat suurimmalta osalta kerätyistä näytteistä Tämän tutkimuksen tarkoituksena on tunnistaa lajikkeita vertaamalla tuntemattomien näytteiden ja tunnettujen lajikkeiden DNA-sormenjälkiä keskenään.

Kaikista 39 toistaiseksi tuntemattomasta $R$. allegheniensis -tyyppisestä kloonista ja kokoelmassa olevista 'Majestät', 'Imprial' ja 'Earliesti of All' -lajikkeista kerättiin lehtinäytteet. DNA eristettiin hiukan muunnellun Nybomin ja Schaalin ohjeen mukaan.

DNA-sormenjälkitekniikka tuotti kaikille tutkituille Rubus-suvun näytteille selkeät kuviot. 'Majestät' ja 'Earliest of All' -lajikkeiden DNA-sormenjäljet erosivat selkeästi toisistaan usean viivan osalta. Tässä tutkimuksessa mukana ollut 'Imperial'-lajikkeen näyte osoittautui puolestaan täysin samanlaisek- si 'Majestät'-lajikkeen kanssa. Jotta taimimateriaalin sekaantuminen tai väärä nimeäminen voitaisiin varmistaa, olisi analysoitava useampia eri lähteistä peräisin olevia 'Imperial'-lajikkeen näytteitä.

Aiemmin tuntemattomasta 39 näytteestä 37 osoittautui täysin samanlaiseksi 'Majestät'-lajikkeen kanssa. Kahden näytteen sormenjälkikuvioista löytyi samalta kohdalta yksi ylimääräinen viiva muutoin täysin samanlaiseen 'Majestät'-lajikkeen kuvioon verrattuna. Muutoksen aiheuttaa todennäköisesti yksittäinen somaattinen mutaatio, mikä yleensä tuottaa hyvin vähäistä vaihtelua DNA-sormenjälkikuvioihin, kuten on todettu esim. omenoilla.

'Majestät'-lajikkeen on aikaisemmin todettu lisääntyvän apomiktisesti, eli suurin osa sen siemenjälkeläisistä on täysin emokasvin kaltaisia. Tämä saattaa olla yksi selitys 'Majestät' ja 'Imperial'-lajikkeiden identtisille DNA-sormenjälkikuvioille. Immonen mainitsee vielä yhden karhunvatukkalajikkeen, 'Wilson's Frühe', joka on ilmeisesti myös samanlainen kuin 'Majestät'. Hämet-Ahdin ja muiden mukaan suurin osa Suomessa viljeltävistä karhunvatukoista muistuttaa $R$. allegheniensis -lajia, ja tämän tutkimuksen tulosten mukaan vain 'Majestät'-lajike tästä ryhmästä on todella menestynyt. 